\title{
EVALUASI PENGGUNAAN OBAT GANGGUAN SALURAN CERNA \\ PADA PASIEN RAWAT INAP BERDASARKAN FORMULARIUM NASIONAL DI FASKES TINGKAT PERTAMA
}

Egi maulana dan Emylia fiskasari

Politeknik Piksi Ganesha Bandung, Indonesia

E-mail: emaulana@piksi.ac.id dan emylia.fiskasari@piksi.ac.id

\section{Diterima:}

25 September

2021

Direvisi:

12 Oktober 2021

Disetujui:

15 Oktober 2021

\section{Abstrak}

Gangguan pencernaan merupakan masalah yang terjadi pada salah satu organ sistem pencernaan, atau lebih dari satu organ pencernaan secara bersamaan. Gangguan saluran cerna yang sering dijumpai di sekitar masyarakat adalah gastroenteritis, dispepsia, gerd dan diare. Penelitian ini menggunakan metode kualitatif deskriptif. Peneliti menggunakan Indikator penggunaan obat yaitu tepat diagnosa, tepat indikasi, tepat dalam pemilihan obat, tepat dosis, efek samping, interval pemerian, dan tepat waktu. Penggunaan obat yang tepat harus disesuaikan dengan formularium yang disusun oleh petugas fasilitas kesehatan untuk memaksimalkan pelayanan kesehatan kepada masyarakat. Hasil penelitian menunjukan bahwa Terdapat 52,5\% tenaga medis yang merasa kurang paham terhadap formularium nasional karena berbagai faktor dari mulai rasa ingin tahu yang kurang atau petugas kefarmasian yang tidak melakukan sosialisasi kepada nakes lainya, dan 30\% nakes menjawab paham terhadap formularium nasional dan 17,5\% menjawab tidak paham. Pengawasan terhadap pasien rawat inap dengan gangguan saluran cerna di faskes tingkat pertama sangat baik, petugas kefarmasian menggunakan form ceklis untuk melihat tingkat kerasionalan penggunaan obat dan indikator peresapan fornas. Tersedianya obat golongan PPI (proton pump inhibitor) yaitu omeprazole 40mg cap dan golongan Histamin $\mathrm{H} 2$-receptor antagonist yaitu ranitidin tablet dan ranitidin sediaan injeksi juga antiemetika sediaan tablet dan sirup yaitu domperidon dan obat tersebut merupakan obat-obat yang harus ada di faskes tingkat pertama.

Kata kunci: evaluasi, Penggunaan obat dan formularium nasional

Abstract
Digestive disorder is a problem that occurs in one organ of the
digestive system, or more than one digestive organ at the same
time. Digestive disorders that are often found around the
community are gastroenteritis, dyspepsia, GERD and diarrhea.
This research uses descriptive qualitative method. Researcher is
using indicators of drug use that are precise diagnosis, exact
indications, appropriate drug selection, the proper dose, side
effects, intervals of assessment, and the right time. The
appropriate use of drugs must be adjusted to the formulary
compiled by health facility workers to maximize health services
to the community. The results showe d that there are $52.5 \%$ of




\section{Pendahuluan}

Permenkes 43 tahun 2019 tentang Puskesmas menyebutkan bahwa Puskesmas adalah Fasilitas Pelayanan Kesehatan (Faskes). Fasilitas Pelayanan Kesehatan adalah suatu tempat yang digunakan untuk menyelenggarakan upaya pelayanan kesehatan, baik promotif, preventif, kuratif maupun rehabilitatif yang dilakukan oleh pemerintah, pemerintah daerah dan/atau masyarakat (Indonesia, 2012). Puskesmas adalah UKM tingkat pertama. UKM dalam Permenkes 43 tahun 2019 tentang Puskesmas dijelaskan bahwa Upaya Kesehatan Masyarakat (UKM) adalah setiap kegiatan untuk memelihara dan meningkatkan kesehatan serta mencegah dan menanggulangi timbulnya masalah kesehatan dengan sasaran keluarga, kelompok, dan masyarakat (Nuriyanto, 2020). Sedangkan Upaya Kesehatan Perseorangan (UKP) adalah suatu kegiatan dan/atau serangkaian kegiatan pelayanan kesehatan yang ditujukan untuk peningkatan, pencegahan, penyembuhan penyakit, pengurangan penderitaan akibat penyakit dan memulihkan kesehatan perseorangan (Umardiono, Andriati, \& Haryono, 2018). Dalam membantu mensejahterakan kesehatan puskemas harus di dukung oleh fasilitas - fasilitas kesehatan diantaranya Instalasi Farmasi guna menunjang dalam pelayanan kesehatan (Indah Aprianti, Rasyid, \& Lestiyani, 2020).

Pelayanan kesehatan yang diberikan kepada masyarakat dalam pelaksanaan Jaminan Kesehatan Nasional (JKN) mencakup pelayanan promotif, preventif, kuratif dan rehabilitative termasuk pelayanan obat sesuai dengan kebutuhan medis (Suhanda, 2015). Dalam mendukung pelaksanaan tersebut, Kementerian Kesehatan, khususnya Direktorat Jenderal Bina Kefarmasian dan Alat Kesehatan berupaya untuk menjamin ketersediaan, keterjangkauan dan aksesibilitas obat dengan menyusun Formularium Nasional (Fornas) yang akan digunakan sebagai acuan dalam pelayanan kesehatan di seluruh fasilitas kesehatan (Safitri, 2018). Gangguan saluran pencernaan merupakan masalah umum yang sering dijumpai di masyarakat (Riyanto \& Suria, 2018). Gangguan saluran cerna yang tidak diterapi dengan benar dapat mengakibatkan keparahan hingga kematian yang sering terjadi di Indonesia, dan berdasarkan penelitian yang dilakukan ditemukan beberapa kasus penyakit gangguan saluran pencernaan seperti kolik abdomen, GEA, konstipasi (Pang, 2013). Obat-obat yang di gunakan untuk perawatan pasien adalah jenis golongan 
pengeblock $\mathrm{H} 2$, antiemetika, anti Diare, proton pump inhibitor dan laxative tersedia dalam berbagai bentuk sediaan seperti injeksi, vial, tablet kapsul dan sirup (Trisa, 2015).

Tujuan penelitian ini adalah melihat dan mengevaluasi sejauh mana penggunaan obat obat gangguan saluran cerna berdasarkan fornas di faskes tingkat pertama,dan melihat sejauh mana kepatuhan tenaga kesehatan dalam penyediaan obat gangguan saluran pencernaan berdasarkan fornas.

\section{Metode Penelitian}

Penelitian ini menggunakan metode kualitatif deskriptif. Penelitian kualitatif adalah penelitian dimana peneliti ditempatkan sebagai instrument kunci, teknik pengumpulan data dilakukan secara penggabungan dan analisis data bersifat induktif (Sugiarto, 2017). Penelitian ini menggunakan desain non eksperiental (observasional) yang bersifat deskriptif, data yang digunakan adalah kualitatif dengan cara pengkajian status pasien rawat inap di puskesmas dan mencocokan dengan resep yang di keluarkan oleh dokter untuk di evaluasi penggunaan obatnya terhadap formularium nasioal pada bulan mei sampai dengan juli 2021. Peneliti bisa mengelompokan jenis obat-obat yang tersedia di fasilitas kesehatan tingkat pertama.

Populasi dari penelitian ini adalah jumlah pasien yang di rawat yang memiliki riwayat gangguan saluran cerna pada bulan mei sampai dengan juli 2021. Sampel adalah bagian dari populasi yang dipilih dengan teknik sampling tertentu untuk bisa mewakili atau memenuhi populasi (Hidayat, 2015). Pengambilan sampel hanya 30\% dari jumlah pasien dalam 3 bulan pada bulan mei sampai dengan juli 2021 (Hathasary, Wiyono, \& Mpila, 2021). Dengan total 254 pasien dari jumlah pasien per 3 bulan itu peneliti mendapatkan 77 pasien. Pengambilan sampel dengan cara mengambil status rekam medis pasien rawat inap pada bulan mei sampai dengan juli 2021 dan mencocokan dengan resep yang di tulis dokter dan di sesuaikan dengan indikator evaluasi penggunaan obat yang sesuai dengan formularium nasional. Teknik analis data adalah proses mencari dan menyusun secaras sistematis. Jumlah pasien rawat inap dengan gangguan saluran cerna di faskes tingkat pertama di daerah cianjur perbulan mei sampai dengan juli adalah 150 pasien dan diambil oleh peneliti $30 \%$ dari jumlah pasien per 3 bulan itu peneliti mendapatkan 77 pasien.

\section{Hasil dan Pembahasan}

Hasil penelitian yang peneliti lakukan selama 3 bulan dari bulan mei sampai juli dengan judul evaluasi "Penggunaan Obat Gangguan Saluran Cerna Pada Pasien Rawat Inap Berdasarkan Formularium Nasional Di Faskes Tingkat Pertama", peneliti bisa mengelompokan jenis obat- obat yang terdapat di faskes ini sebagai berikut :

Tabel 1. Jenis Obat Fornas Yang Ada Di Faskes Tingkat Pertama

\begin{tabular}{lll}
\hline $\begin{array}{l}\text { Nomor } \\
\text { Kelas } \\
\text { Terapi }\end{array}$ & $\begin{array}{l}\text { Numa Kelas Terapi,Nama } \\
\text { Generik }\end{array}$ & $\begin{array}{l}\text { Formulasi (Bentuk Sediaan } \\
\text { dan Kemasan }\end{array}$ \\
\hline \multicolumn{3}{c}{ SALURAN CERNA } \\
\hline A. & Antasida dan Anti Ulkus \\
\hline 1 & Antasida DOEN I & Tab kunyah \\
\hline & & Suspensi $60 \mathrm{ml}$ \\
\hline 2 & Omeprazole & Kaps 20 mg \\
\hline
\end{tabular}




\begin{tabular}{|c|c|c|}
\hline 3 & Ranitidine & Tab $150 \mathrm{mg}$ \\
\hline & & Injeksi $25 \mathrm{mg} / \mathrm{ml}$ \\
\hline \multirow[t]{3}{*}{ B. } & Antiemetik & \\
\hline & Domperidon & Tab $10 \mathrm{mg}$ \\
\hline & & Syr $5 \mathrm{mg} / 5 \mathrm{~mL}$ \\
\hline \multirow[t]{5}{*}{ C. } & DIARE & \\
\hline & Atapulgit & Tab $600 \mathrm{mg}$ \\
\hline & Garam Oralit & Serbuk \\
\hline & Zinc & Tab $20 \mathrm{mg}$ \\
\hline & & Syr $20 \mathrm{mg} / 5 \mathrm{~mL}$ \\
\hline
\end{tabular}

Dari hasil pengamatan terdapat beberapa obat gangguan saluran cerna yang masuk ke dalam formularium nasional dan di gunakan oleh pasien rawat inap, peneliti menemukan 5 item obat dan masih banyak obat yang harusnya ada di faskes pertama berdasarkan fornas, tapi nyatanya tidak tersedia di faskes tingkat pertama.

Diagram 1. jumlah pasien rawat inap dengan ganguan saluran cerna.

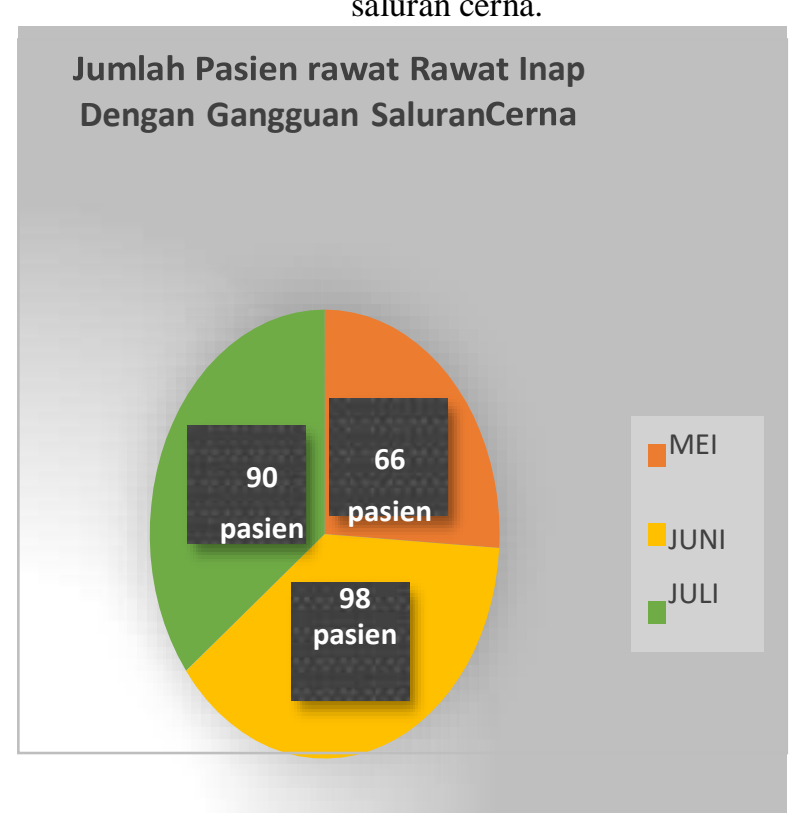

Dari pengamatan peneliti mencatat jumlah pasien rawat inap yang memiliki gangguan sistem pencernaan total pasien pada 3 bulan terakhir yaitu mei, juni dan juli adalah 254 pasien, 66 pasien pada bulan mei, 98 pasien juni dan 90 pasien pada bulan juli. 
Diagram 2. jumlah pasien dengan gangguan saluran cerna

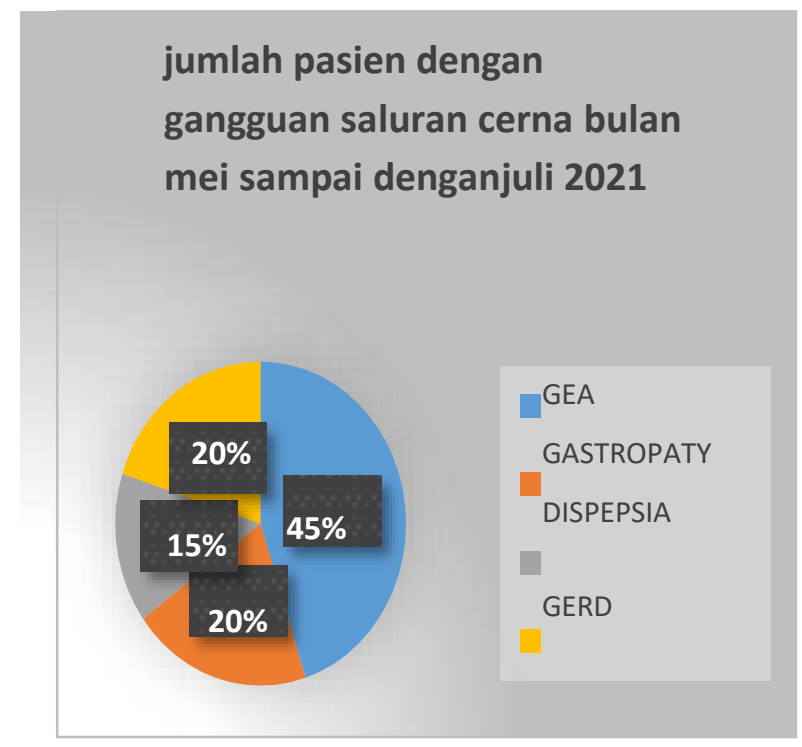

Peneliti mengelompokan 4 penyakit gangguan saluran cerna yang memiliki prioritas yang harus di tangani di faskes tingat pertama, yaitu $45 \%$ pasien mengalami gangguan GEA (Gastroenteritis ), 20\% pasien mengalami Gastropathy, 15\%. Berdasarkan penelitian yang peneliti lakukan melalui google form yang dibagikan kepada 97 tenaga kesehatan terdapat 52,5\% tenaga medis merasa kurang paham terhadap formularium nasional karena berbagai faktor dari mulai rasa ingin tahu yang kurang atau petugas kefarmasian yang tidak sering melakukan sosialisasi kepada nakes, dan 30\% nakes menjawab paham terhadap formularium nasional dan $17,5 \%$ menjawab tidak paham. Penelitian ini menggunakan metode deskriptif kualitatif. Pengumpulan data dalam penelitian ini dilakukan observasi dan dokumentasi. Dalam penelitian ini diambil jumlah pasien dari tiga bulan yaitu yaitu mei juni dan juli adalah 254 pasien, 66 pasien pada bulan mei, 98 pasien juni dan 90 pasien pada bulan juli untuk di evaluasi penggunaan obat gangguan saluran cerna pada pasien rawat inap berdasar formularium nasional di faskes tingkat pertama. Terdapat 5 jenis obat yang sesuai dengan formularium nasional untuk pasien rawat inap di faskes pertama, dan masih banyak obat- obatan yang tidak ada di faskes pertama padahal di fornas harus ada untuk pelayanan kesehatan di faskes tingkat pertama (Arifin, Pasinringi, \& Palu, 2018). Berdasarkan penelitian yang peneliti lakukan melalui google form yang dibagikan kepada 97 tenaga kesehatan terdapat 52,5\% tenaga medis merasa kurang paham terhadap formularium nasional karena berbagai faktor dari mulai rasa ingin tahu yang kurang atau petugas kefarmasian yang tidak sering melakukan sosialisasi kepada nakes, dan 30\% nakes menjawab paham terhadap formularium nasional dan $17,5 \%$ menjawab tidak paham. Pengawasan terhadap pasien rawat inap dengan gangguan saluran cerna di faskes tingkat pertama cukup baik pasien mengalami Dispepsia dan $20 \%$ pasien mengalami Gerd. 


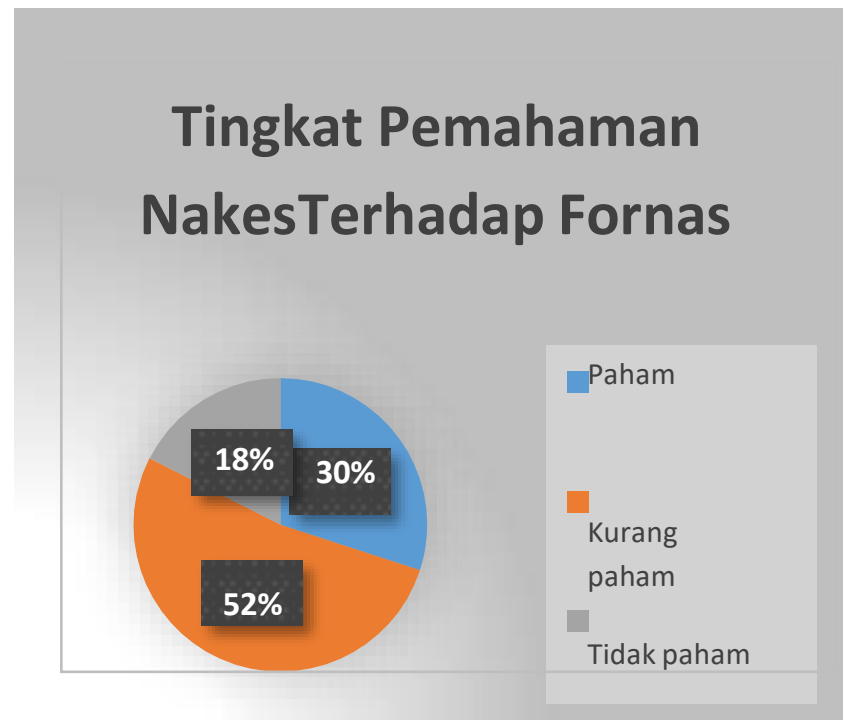

Dokter menulis di resep dan status rekam medis pasien jika ada pasien yang membutuhkan obat-obat, dan perawat mengawasi penggunaan obatnya dan memantaunya melalui rekam medis pasien dan petugas kefarmasian memantaunya setiap pagi ketika memberikan obat oral kepada pasien. Selama penelitian yang dilakukan di faskes tingkat pertama khususnya di daerah Cianjur, semua resep yang dokter keluarkan sesuai dengan formularium nasional, dokter selalu menanyakan jenis obat yang bisa digunakan untuk pasien rawat inap yang sesuai formularium nasional. Peneliti menggunakan tabel untuk menyesuaikan resep yang dokter keluarkan dengan indikator penggunaan obat dan indikator formularium nasional.

Obat-obat yang harus ada di faskes tingkat pertama berdasarkan formularium nasional yaitu untuk golongan PPI yaitu omeprazole 40mg vial dan golongan $\mathrm{H} 2$ yaitu simetidin tablet dan ranitidin sediaan injeksi juga antiemetika sediaan sirup yaitu domperidon dan metoclorpamide, hanya ada 5 jenis obat yang ada di faskes tingkat pertama dan itupun stocknya menipis (Sutrisna, 2013). Upaya yang harus dilakukan untuk masalah evaluasi penggunaan obat gangguan saluran cerna untuk pasien rawat inap di puskesmas adalah dari segi tenaga kesehatan, pihak puskesmas atau faskes pertama harus lebih sering melakukan sosialisasi dan pelatihan menyangkut formularium nasional karena ini sangat penting menyangkut pelayanan terhadap masyarakat (Nurhani \& Rahmadani, 2020).

\section{A. Kesesuain Dengan Indikator Penelitian}

1. Ketepatan dosis

Penggunaan obat disebut rasional jika diberikan dengan diagnosis yang tepat. Jika diagnosis tidak ditegakkan dengan benar, maka pemilihan obat akan terpaksa mengacu pada diagnosis yang keliru tersebut.Akibatnya obat yang diberikan juga tidak akan sesuai dengan indikasi yang seharusnya.berdasarkan penelitian yang dilakukan hampir $100 \%$ penggunaan obat di faskes pertama ini tepat untuk dosis.

2. Tepat indikasi 
Setiap obat memiliki spektrum terapi yang spesifik. Termasuk untuk obat gangguan saluran cerna,pengobatan dikatakan tepat jika obat di berikan sesuai indikasi pasien, dan berdasarkan penelitian hampir $98 \%$ pasien mendapatkan ketepatan dalam indikator tepat indikasi.

3. Tepat pemilihan obat

Sama seperti tepat indikasi, pemelihan obat harus sesuai dengan keadaan pasien dan berdasarkan penelitian yang peneliti lakukan tepat pemlihihan obat mencapai $100 \%$ di lakukan oleh pemeriksa.

4. Tepat dosis

Tepat dosis adalah hal sangat penting untuk keberhasilan pengobatan dan berdasarkan penelitian yang peneliti lakukan $100 \%$ dokter tepat dalam menentukan dosis untu pasien.

5. Tepat waktu interval pemberian

Untuk waktu interval pemberian obat semakin banyak interval waktu maksa semakin rendahkepatuhan pasien untuk minum obat, karena dengan pengawasan ketat yang di lakukan oleh petugas jaga waktu meminum obat bisa di ingatkan setiap pasienya meskipun pasien harus meminum obat sehari 4 kali seperti pada pemberian antibiotik jenis clorampenicol 250mg.

6. Efek samping

Efek samping merupakan hal sangat penting yang harus di pahami oleh petugas kesehatan untuk memaksimalkan pelayanan kesehatan kepada pasien berdasarkan penelitian yang peneliti lakukan kejadian untuk efek samping obat terjadi 0 KASUS karena petugas mengkaji dengan benar obat-obat yang akan di beriakn kepada pasien dengan pengawasan oleh petugas yang melakukan dinas.

\section{B. Keseuaian Dengan Indikator Formularium Nasional}

1. Efisiensi

Kemudahan pengadaan obat apabila formularium yang di jadikan acuan untuk pengadaan obat, setelah peneliti melakukan observasi faskes tingkat pertama khususnya puskesmas di beriaknkemudahan untuk pengadaan melalui E-catalog.

2. Efektivitas

Efektifitas untuk pasien dan puskesmas sangat baik di rasakan karena fornas di susun oleh orang-orang yang kompeten di bidangnya dan di sesuaikan dengan kebutuhan fasilitas kesehatan tingkat pertama, dan obat-obat yang di wajibkanada di faskes pertama sangat terjangkau harganya untuk dilakukan pengadaan oleh puskesmas.

3. Keselamatan pasien

Pengawasan yang di lakukan panitia pembentuk formularium sangat ketat karena formularium nasional di susun oleh orang-orang kompeten di bidangnya. Formularium di bentuk untuk menyesuaikan kebutuhan obat untuk pasien di setiap faskes. Berdasarkan penelitian yang di lakukan peneliti formularium sangat bagus dan baik di gunakan di faskes pertama dan sejauh ini penggunaan formas masih berjalan baik dengan pengawasan dari pusat.

\section{Kesimpulan}

Terdapat 52,5\% tenaga medis yang merasa kurang paham terhadap formularium nasional karena berbagai faktor dari mulai rasa ingin tahu yang kurang atau petugas kefarmasian yang tidak sering melakukan sosialisasi kepada nakes, dan 30\% nakes menjawab paham terhadap formularium nasional dan $17,5 \%$ menjawab tidak paham. Pengawasan terhadap pasien rawat inap dengan gangguan saluran cerna di faskes tingkat 
pertama cukup baik dokter menulis di resep dan status rekam medis pasien jika ada pasien yang membutuhkan obat- obat, dan perawat mengawasi penggunaan obatnya dan memantaunya melalui rekam medis pasien dan petugas kefarmasian memantaunya setiap pagi ketika memberikan obat oral kepada pasien. Semua resep yang dokter keluarkan sesuai dengan formularium nasional, dokter selalu menanyakan jenis obat yang bisa digunakan untuk pasien rawat inap yang sesuai formularium nasional.

Tersedianya obat golongan PPI yaitu omeprazole 40mg cap dan golongan $\mathrm{H} 2$ yaitu ranitidn tablet dan ranitidin sediaan injeksi juga antiemetika sediaan tablet dan sirup yaitu domperidon dan obat tersebut merupakan obat-obat yang harus ada di faskes tingkat pertama. Upaya yang harus dilakukan untuk masalah evaluasi penggunaan obat gangguan saluran cerna untuk pasien rawat inap di puskesmas adalah dari segi tenaga kesehatan, pihak puskesmas atau faskes pertama harus lebih sering melakukan sosialisasi dan pelatihan menyangkut formularium nasional karena ini sangat penting menyangkut pelayanan terhadap masyarakat.

\section{Bibliografi.}

Arifin, Nur Fadhilah, Pasinringi, Syahrir A., \& Palu, Basir. (2018). Kepuasan Kerja Tenaga Medis pada Era Jaminan Kesehatan Nasional Work Satisfaction of Medical Personnel Era National Health Insurance.

Hathasary, Rochmat Hidayat, Wiyono, Weny, \& Mpila, Deby Afriani. (2021). Evaluasi Penggunaan Obat Pada Pasien Ppok (Penyakit Paru Obstruktif Kronis) Di Instalasi Rawat Jalan Rsup Prof. Dr. Rd Kandou Manado. Pharmacon, 10(1), 630-638.

Hidayat, Aziz Alimul. (2015). Metode penelitian kesehatan paradigma kuantitatif. Health Books Publishing.

Indah Aprianti, SIP162321, Rasyid, Amhar, \& Lestiyani, Tri Endah Karya. (2020). Pelayanan Kesehatan Dasar Gratis Berkualitas (Studi Implementasi Peraturan Daerah Nomor 4 Tahun 2014 Kabupaten Tanjung Jabung Timur Provinsi Jambi). Jambi: UIN Sulthan Thaha Saifuddin Jambi.

Indonesia, Presiden Republik. (2012). Peraturan Pemerintah Republik Indonesia nomor 33 tahun 2012 tentang pemberian air susu ibu eksklusif. Lembaran Negara RI Tahun, (58).

Nurhani, Nurhani, \& Rahmadani, Suci. (2020). Analisis Pelaksanaan Sistem Rujukan Pasien Bpjs Kesehatan Di Puskesmas Mamasa, Puskesmas Malabo Dan Puskesmas Balla Kabupaten Mamasa. Jurnal Publikasi Kesehatan Masyarakat Indonesia, 7(2).

Nuriyanto, Andy. (2020). PERKESMAS: Aplikasi Keperawatan Profesional di Puskesmas. Gmb-Indonesia.

Pang, Maria Rosari Quincy. (2013). Penatalaksanaan Gangguan Saluran Pencernaan di Rumah Sakit Panti Rini Yogyakarta Periode Juli 2012 Kajian: Dosis Obat Dan Kemungkinan Interaksi Obat. Skripsi.

Riyanto, Nur Budi, \& Suria, Ozzi. (2018). Sistem Pakar Diagnosa Penyakit Pencernaan Menggunakan Metode Teorema Bayes. JMAI (Jurnal Multimedia \& Artificial Intelligence), 2(1), 7-12.

Safitri, Lina. (2018). Gambaran Kesesuaian Peresepan Obat Pasien Bpjs Rawat Jalan Dengan Formularium Nasional Di Poliklinik Ayodya Rsj Prof. Dr. Soerojo Magelang. Magelang: Skripsi, Universitas Muhammadiyah Magelang.

Sugiarto, Eko. (2017). Menyusun proposal penelitian kualitatif: Skripsi dan tesis: Suaka media. Yogyakarta: Diandra Kreatif.

Suhanda, Rachmad. (2015). Jaminan Kesehatan Dan Managed Care. Jurnal Kedokteran Syiah Kuala, 15(2), 104-113.

Sutrisna, Aang. (2013). Dampak HIV Pada Pendidikan Anak di Indonesia. Prosiding 
Child Poverty and Social Protection Conference. Jakarta.

Trisa, Agung Prakoso. (2015). Evaluasi Drug Related Problems Kategori Penyesuaian Dosis Pada Pasien Gagal Ginjal Kronik di Rumah Sakit Pelabuhan Jakarta Utara. Umardiono, Andi, Andriati, Andriati, \& Haryono, Nanang. (2018). Peningkatan Pelayanan Kesehatan Puskesmas Untuk Penanggulangan Penyakit Tropis Demam Berdarah Dengue. JAKPP (Jurnal Analisis Kebijakan \& Pelayanan Publik), 60-67.

$$
\text { (c) } \frac{1}{\text { ar }(2)}
$$

This work is licensed under a Creative Commons Attribution-ShareAlike 4.0 International License. 